\title{
BERITA SEBAGAI REPRESENTASI IDEOLOGI MEDIA (Sebuah Telaah Kritis)
}

\author{
Acan Mahdi
}

\begin{abstract}
ABSTRAK
Tulisan ini hanya telaah singkat mengenai praktik pewacanaan dalam media massa. Berita dan artikel media massa merupakan bagian kecil dari praktik pewacanaan. Bagaimana berita atau sebuah artikel disuguhkan kepada publik, sangat ditentukan oleh ideologi yang dianut oleh media tersebut. Singkatnya, dalam praktik pewacaanan yang terpenting bukan "apa" yang diangkat, namun lebih pada bagaimana berita ditulis oleh media masa. Karena bagimana sebuah fakta sosial digambarkan oleh media masa merupakan representasi dari ideologi yang bersemayam di belakangnya. Dalam konteks, peranan bahasa sangat menentukan dalam pertarungan wacana.
\end{abstract}

Kata Kunci: berita, ideologi, media

\section{A. Media Massa dan Kritikal Teori}

Dalam paradigma kritis, asumsi yang berlaku terhadap media adalah wacana kecurigaan. Segala bentuk wacana dalam media harus dicurigai pemaknaanya dalam konteks fenomena yang terjadi di masyarakat. Di sini terdapat anggapan bahwa tidak yang netral di bumi ini. Segala sesuatu yang terjadi di bumi ini tidak terlepas dari kepentingan, nilai-nilai dan ideologi yang diyakini dan berlaku di masyarakat. Demikian juga pemaknaan tradisi kritis terhadap media dan pers. Media dan segala yang ada di dalamnya termasuk berita yang disampaikan kepada masyarakat tidaklah bebas nilai dan tanpa kepentingan. Berita yang setiap hari kita baca melaui koran, majalah, bulletin, media visual maupun audiovisual lainnya merupakan dialektika antara fenomena yang terjadi dan nilai-nilai yang berlaku di masyarakat, termasuk nilai-nilai dan kaedah-kaedah yang berlaku dimedia masa dan pers itu sendiri. Menurut Piliang (2004: 133), ada dua kepentingan besar yang bekerja dibalik media, yaitu kepentingan ekonomi (ekonomic interest) dan kepentingan kekuasaan (power interest). Relasi antara kedua hal itulah, jelas Piliang, yang kemudian membentuk isi media (media content). 
Tradisi kritis menelisik jauh lebih dalam, mengamati keseluruhan proses yang terjadi di newsroom, teks, kontekstual serta nilai-nilai dan ideologi yang bermain dibelakang media. Teori kritis (Bungin, 2008: 259) selalu mengkaji kondisi-kondisi sosial dalam usahanya untuk mengungkap struktur-struktur yang sering tersembunyi. Bungin, selanjutnya menjelaskan bahwa pengetahuan adalah kekuatan untuk memahami bagaimana seseorang ditindas sehingga orang dapat mengambil tindakan untuk mengubah kekuatan penindas. Sejalan dengan apa yang dikatakan Bungin di atas, Guba dan Lincoln (2009: 138) mengatakan bahwa "suara" yang kembangkan teori kritis adalah "suara" intelektual transformatif sebagai pembela dan aktivis.

Dalam banyak kajian sosial budaya, ekonomi dan politik, kehadiran media tidak dapat dinafikan begitu saja. Media selalu ditepatkan sebagai variabel determinan dalam mempangaruhi persepsi dan opini bublik. Sebagaimana dikatakan Deutch (dalam Effendy, 2000: 325), media merupakan "the Nerves of government". Deutch mensinyalir bahwa hanya mereka yang memiliki pemahaman atau akses informasi, yang menguasai percaturan kekuasaan. Pernyataan Deutch di atas bukanlah tanpa alasan - dan memang begitu nyatanya.

Media dengan kelebihan yang dimilikinya, lebih-lebih media audiovisual yang dapat menjangkau pemirsa di rumah dalam space yang lebih luas dengan simultan, menjadikan dirinya "hulu ledak" dengan daya gempur yang lebih dahsyat. Persis, fakta ini menjadikan media sebagai entitas yang sangat strategis bagi kelas tertentu dalam rangka tranformasi nilai-nilai dan ideologi kepada khayak, pembaca, pendengar dan penonton di rumah. Pihakpihak yang berkepentingan berebut pengaruh, dalam melancarkan ideologinya melalui media.

Jauh sebelumnya, Gramsci (dalam Patria, 2003: 127) menjelaskan bahwa dalam membentuk konsensus seperti apa yang diinginkan, kelas tertentu biasanya menggunakan mekanisme kelembagaan sebagai transmisi. Media adalah salah satu mekanisme kelembagaan itu, yang menurut Gramsci sebagai "tangan-tangan" kelompok yang berkuasa untuk menentukan ideologi yang mendominir. Bahasa, dalam pandangan Gramsci menjadi sarana penting untuk melayani fungsi hegemonis itu. Konflik sosial yang ada dibatasi baik intensitas maupun ruang lingkupnya, karena ideology yang ada membentuk keinginan-keinginan, nilai-nilai dan harapan menurut system yang telah ditentukan.

Sangatlah beralasan apa yang dijelaskan Gramsci, bahwa media merupakan "tangan-tangan" kelompok tertentu untuk menentukan ideologi yang mendominir, yang akhirnya bermuara pada 
hegemoni terhadap golongan lainnya.

Mengingat, media dalam kerjanya membentuk opini dan persepsi dan bahkan hegemoni terhadap masyarakat melalui consensus - bukan suatu pemakasaan dengan penindasan dan kekerasan.

Dalam konteks ini, tidaklah berlebihan jika kita katakan bahwa proses kerja media dalam menghegemoni masyarakat adalah proses kerja alam bawah sadar. Sesuatu yang tidak kita sadari dengan indra "telanjang". Hall (dalam Em Grifin, 2003: 369) menjelaskan bahwa hegemoni media bukan merupakan alur cerita yang sadar, tidak teralu menekan, kursif, dan pengaruhpengaruhnya tidak total. Penyiaran dan media cetak, jelas Hall, menyajikan beragam gagasan-gagasan kemudian mereka cenderung untuk mendukung status quo dengan mengistimewakan tentang realita yang telah diterimanya. Hasilnya, peran media masa ternyata menjadi produksi persetujuan, bukannya pencerminan dari konsensus yang sudah ada. Produksi persetujuan menurut Chris Barker (2000: 11) berarti khalayak ramairamai mengidentifikasi diri dengan maknamakna kultural yang dibentuk lewat praktikpraktik signifikasi teks hegemonik.

\section{B. Ideologi dan Kepentingan Politik Media}

Jika kita membaca Surat Kabar Kompas terkait kemelut Palestina - Israel, maka kita akan dapatkan bahwa bangsa Palestina dengan unsur-unsur yang terkait dengannya adalah atau seolah biang dari segala kemelut yang terjadi. Bangsa Palestina ddwacanakan sebagai bangsa yang anti perdamaian, identik dengan bom, selalu menebar teror dan ketakutan terhadap bangsa Yahudi, yang pada akhirnnya menciptakan reaksi dari bangsa Yahudi, dengan membalas atau membela diri dari serangan bom atau kekerasan yang dilakukan oleh pihak Palestina. Dalam konteks ini, Bangsa Palestina digambarkan sebagai pihak yang aktif dalam menyulut koflik, semantara bangsa Yahudi dideskripsikan sebagai anak manis yang hanya membela diri dari kekerasan dan serangan bangsa Palestina.

Sebaliknya, akan terjadi kontradiktif jika kita membaca Surat Kabar Republika mengenai kemelut yang terjadi antara Palestina dan Israel itu. Surat Kabar Republika, sebaliknya, melihat kemelut yang terjadi sebagai akibat inperialisme yang dilakukan oleh bangsa Yahudi terhadap Palestina. Kererasan, teror, dan bom yang dilakukan pihak Palestina dengan berbagai macam elemen yang berafiliasi dengannya, diwacanakan sebagai aksi menentang atau aksi membela tanah air dari keangkuhan inperialisme bangsa Yahudi. Dalam konteks ini, bangsa Yahudi digambarkan sebagai pihak yang aktif dalam menyulut "api" konflik, sementara teror, bom, dan 
kekerasan yang dilakukan oleh rakyat Palestina diwacanakan bentuk ijtihat dalam rangka membebaskan diri dan bangsa dari inperialisme Yahudi.

Berita sebagai hasil konstruksi media bukanlah hadir dengan sendirinya. Media dan berita tidak hadir diruang vakum, tapi hidup di tengah-tengah realitas sosial yang sarat konflik, nilai-nilai dan ideolgi. Berita dengan demikian merupakan refleksi dialektika fenomena sosial dengan nilai-nilai dan ideologi yang berlaku di sebuah entitas, dengan media sebagai agen konstruksinya. Berita, dengan sendirinya mencerminkan ideologi dan keyakinan entitas yang mendominasi di sebuah entitas.

Para teoritisasi berbeda pandangan dalam memaknai kata ideologi, sesuai dengan sudut pandang masing-masing. Gramsci (dalam Syaiful Arief, 2001: 68) misalnya. Bagi Gramsci, ideologi dimaknai historis (historically organics ideologi). Menurutnya, ideologi harus menjadi suatu kesadaran kolektif yang mampu mengakomodasikan kepentingan kelompok lain dan menarik kelompok lain itu ke kelompok "penghegemoni".

Ideologi bagi Althusser (1989) bukan "kesadaran palsu" seperti yang dikatakan Karl Marx, melainkan profoundly unconcius, sebagai hal-hal yang secara mendalam tidak disadari, yang tertanam dalam diri individu sepanjang hidupnya. History turn into nuture, produk sejarah yang seolah-oleh menjelma jadi sesuatu yang alamiah. Kepercayaan yang tertanam tanpa disadari itulah yang dinamakan ideologi.

Raymond William (dalam Fiske, 1990: 164), mengklasifikasikan penggunaan ideologi tersebut dalam tiga ranah. Pertama, sebuah sistem kepercayaan yang dimiliki oleh kelompok atau satu kelas tertentu. Definisi ini jelasnya, terutama dipakai oleh kalangan psikologis yang melihat ideologi sebagai seperangkat sikap yang dibentuk dan diorganisasikan dalam bentuk yang koheren. Kedua, sebuah sistem kepercayaan yang dibuat - ide palsu atau kesadaran palsu - yang bisa dilawankan dengan pengetahuan ilmiah. Ideologi dalam pengertian ini adalah seperangkat kategori yang dibuat dan kesadaran palsu dimana kelompok yang berkuasa atau dominan menggunakannya untuk mendominasi kelompok lain yang tidak dominan. Karena kelompok yang dominan mengontrol kelompok lain dengan menggunakan perangkat ideologi yang disebarkan ke dalam masyarakat, akan membuat kelompok yang didominasi melihat hubungan tampak natural, dan diterima sebagai kebenaran. Di sini, ideologi desebarkan lewat berbagai instrumen dari pendidikan, politik, sampai media massa. Ideologi di sini bekerja dengan membuat hubungan-hubungan sosial tampak nyata, wajar dan alamiah, 
dan tanpa sadar kita menerima sebagai kebenaran.

Terkait peranan media dalam mengukuhkan ideologi tertentu, Eriyanto (2001: 103), menjelaskan bahwa Gramsci membangun suatu teori yang menekankan bagaimana penerimaan kelompok yang didominasi terhadap kehadiran kelompok dominan berlangsung dalam suatu proses yang damai, tanpa tindakan kekerasan. Media dapat menjadi sarana di mana suatu kelompok mengukuhkan posisinya dan merendahkan kelompok lain. Ini bukanlah berarti media adalah kekuatan jahat yang secara sengaja merendahkan masyarakat bawah. Proses bagaimana wacana mengenai bagaimana gambaran masyarakat kelas bawah bisa buruk di media, berlangsung dalam proses yang komplek. Proses marjinalisasi wacana itu berlangsung secara wajar, apa adanya, dan dihayati bersama. Khalayak tidak merasa dibodohi atau dimanipulasi oleh media. Konsep hegemoni menolong kita menjelaskan bagaimana proses ini berlangsung.

Menurut Gramsci, kekuatan dan dominasi kapitalis tidak hanya melalui dimensi material dari sarana ekonomi dan relasi produksi, akan tetapi kekuatan (force) dan hegemoni. Jika yang pertama menggunakan daya paksa untuk orang banyak mengikuti dan mematuhi syaratsyarat suatu cara produksi atau nilai-nilai tertentu, maka yang terakhir meliputi peluasan pelestarian "kepatuhan aktif" (secara sukarela) dari kelompok-kelompok yang didominasi oleh kelas penguasa lewat prektek penggunaan kepemimpinan intelektual, moral dan politik.

Menurut Santoso \& Sunarto (2003: 89), konsep hegemoni Gramsci, diambil secara dialektis melalui dikotomi tradisional yang berkarakteristik pemikiran Italia, yakni dari Machiavelli (kekuatan, farce) sampai Pareto (persetujuan, consent), dan dengan Lenin (strategi). Teori Gamsci tentang hegemoni, jelasnya merupakan langkah maju dalam rangka menyelamatkan Marxisme itu sendiri dari defenisi yang pasif tentang revolusi. Teori hegemoni tambahnya, sesungguhnya merupakan kritik inplisit terhadap reduksionisme dan esensialisme yang melanda banyak penganut Marxisme dan juga non-Marxian. Reduksionisme dan esensialisme menurut Faqih (pengantar, dalam Simon, 1999: xiv) adalah paham yang mereduksi dan menganggap esensi sebagai sebuah entitas tertentu yang bertindak sebagai kebenaran mutlak dan doktrin yang sesungguhnya benar.

Hegemoni (Patria \& Arif, 1999: 121) merujuk pada pengertian tentang situasi sosial politik yang dalam terminologi Gramsci disebut 'momen', di mana filsafat dan praktik sosial masyarakat menyatu dalam keadaan seimbang. Dominansi merupakan konsep dari realitas yang menyebar melalui masyarakat dalam 
sebuah lembaga dan manifestasi perorangan. Pengaruh spirit ini berbentuk moralitas, adat, religi, prinsip politik dan semua relasi sosial, terutama dari intelektual. Hegemoni selalu berhubungan dengan penyusunan kekuatan negara sebagai kelas diktator. Konsep hegemoni ini menurut Patria dan Arif (1999: 121) dapat dilacak melalui penjelasan Gramsci tentang Supremasi kelas. Menurutnya supremasi sebuah kelompok mewujud dalam dua cara: dominasi dan kepeminpinan intelektual. Hegemoni menunjuk pada kuatnya pengaruh kepemimpinan dalam bentuk moral maupun intelektual, yang membentuk sikap kelas yang dipimpin. Ini terjadi dalam citra konsensual. Konsensus yang terjadi antara dua kelas ini diciptakan melalui pemaksaan maupun pengaruh terselubung melalui pengetahuan yang disebarkan perangkat-perangkat kekuasaan. Dengan kata lain, hegemni adalah sebuah rantai kemenangan yang didapat melalui mekanisme konsensus daripada melalui penindasan terhadap kelas sosial lainnya. Pada hakikatnya, hegemoni merupakan upaya untuk menggiring orang agar menilai dan memandang problematika sosial dalam kerangka yang ditentukan.

Tidak jauh berbeda, Yudi Latif (dalam Subandy Ibrahim \& Djamaludin Malik, 1997: 294), mengatakan bahwa hegemoni menekankan pada bentuk ekspresi, cara penerapan, mekanisme yang dijalankan untuk dipertahankan, dan mengembangkan diri melalui kepatuhan para korbannya, supaya upaya itu berhasil mempengaruhi dan membentuk alam pikiran mereka.

Raymond William (Berger, 1991: 49) menjelaskan bahwa, hegemoni bekerja melalui dua saluran: ideologi dan budaya melalui mana nilai-nilai itu bekerja. Melalui hegemoni, ideologi kelompok dominan dapat disebarkan, nilai dan kepercayaan dapat dipertukarkan. Akan tetapi, berbeda dengan manipulasi atau indoktrinasi, hegemoni justru terlihat wajar, orang menerima sebagai kewajaran dan sukarela. Ideologi hegemonik itu menyatu dan tersebar dalam praktik kehidupan, persepsi, dan pandangan dunia sebagai sesuatu yang dilakukan dan dihayati secara sukarela.

Terkait peranan media dalam mengukuhkan ideologi tertentu, Eriyanto (2001: 103), menjelaskan bahwa Gramsci membangun suatu teori yang menekankan bagaimana penerimaan kelompok yang didominasi terhadap kehadiran kelompok dominan berlangsung dalam suatu proses yang damai, tanpa tindakan kekerasan. Menurut Eriyanto, media dapat menjadi sarana di mana suatu kelompok mengukuhkan posisinya dan merendahkan kelompok lain. Ini bukanlah berarti media adalah kekuatan jahat yang secara sengaja merendahkan masyarakat bawah. Proses bagaimana wacana mengenai 
bagaimana gambaran masyarakat kelas bawah bisa buruk di media, berlangsung dalam proses yang komplek. Proses marjinalisasi wacana itu berangsung secara wajar, apa adanya, dan dihayati bersama. Khalayak tidak merasa dibodohi atau dimanipulasi oleh media.

Sebagai agen konstruksi, media merupakan wadah yang strategis dalam rangka mengkonstruksi realitas sosial. Hal ini, merujuk kepada berbagai macam kepentingan di dalamnya, baik politik, ekonomi, sosial budaya dan agama. Dalam konteks politik dan kekuasaan, media, sebagaimana penjelasan sebelumnya, menjadi alat yang hegemoni untuk mempertahankan dominasi dan kekuasaan kelas yang mendominasi.

Dalam prakteknya, suatu media melakukan seleksi terhadap wacana (berita) yang akan siarkan. Proses ini adalah keseluruhan aktivitas yang komplek dan rumit. Tidak sekedar itu, proses selektif juga dikakukan dalam penempatan terhadap berita tertentu, pilihan kata, struktur bahasa, dan gaya bercerita yang telah ditetapkan. Dalam kajian kritis, proses ini biasanya disebut framing, yaitu bagaimana media membingkai sebuah peristiwa sosial dalam realitas konstruksinya (berita).

Kajian kritis memandang bahwa proses produksi berita di madia massa merupakan pertarungan ideologis atau kepentingan tertentu. Pertarungan itu yang kemudian menghasilkan teks berita sebagai simbol-simbol yang mencerminkan dominasi ide dan kepentingan dari kelompok yang memenangkannya. News room sebagaimana arena sosial lainya terdiri dari seperangkat struktur dan agensi serta hubungan-hubungan di antaranya. Struktur dalam news room dapat berupa peraturan yang tertulis maupun tidak tertulis, kebiasaan-kebiasaan, sumber daya dibutuhkan untuk beroperasinya news room tersebut, serta tatanan hubungan antara human agent yang berinteraksi di dalamnya. Human agent merujuk pada setiap orang yang memiliki wewenang dan tanggung jawa masingmasing dalam news room, yaitu wartawan, editor, redaktur, kameramen, presenter, penanggung jawab, bidang usaha, wakil penguasa atau negara dan lain-lain. Sedangkan agensi adalah tindakantindakan sosial dari para human agents tersebut. Dedy Hidayat (2000: 432), menjelaskan pilihan terhadap dualitas dan dualisme sruktur-agensi harus harus dilakukan sesuai dengan kondisi empirik dan spesifik. Masing-masing memiliki tugas dan wewenang tersendiri. Dalam suatu setting sosial tertentu, konsepsi dualisme mungkin lebih tepat, namun dalam setting yang lain konsep dualisme justru lebih memadai.

Terkait posisi struktur dan human agent, dapat dilihat dengan dua pendekatan. Pertama, adalah menurut 
pandangan aliran instrumentalism, human agent selalu dapat menjadikan media (termasuk strukturnya) sebagai instrumen mereka. Chomsky dan Herman (1988: xi) adalah orang yang pernah menggambarkan dimana pemilik modal mampu menetapkan premis-premis wacana publik, menentukan informasi apa yang boleh dikonsumsi publik dan terus menerus mengelola pendapat publik melalui propaganda. $\mathrm{Di}$ sisi lain pendekatan ini juga mengakui kemanpuan jurnalis untuk memproduksi berita sebagaimana yang mereka inginkan, dan karena itu jurnalis juga dapat menjadikan media sebagai instrumen mereka.

Kedua, dengan pendekatan strukturalisme. Pendekatan strukturalism berpendapat bahwa isi media semata-mata merupakan representasi dari struktur yang ada, mengabaikan interaksi sosial antara agen pelakunya. Bahkan menurut Schudson (Hidayat, 2000: 437) mengatakan hasil dari produksi berita berkaitan langsung dengan struktur ekonomi media atau industri media. Sedangkan hal-hal lain di antaranya merupakan sebuah "black box" yang tidak bermanfaat untuk diperiksa. Dalam konteks ini, Golding dan Murdoch (J. Curran, dalam J. Curran \& M. Gurevitch, 1996: 19) memberikan alternatif lain dengan menyatakan bahwa sesungguhnya terdapat interplay antara struktur dan agensi. Dijelaskan Golding dan Murdoch bahwa, human agent beroperasi dalam struktur - struktur yang mungkin saja menghambat atau memfasilitasi, memaksa batas - batas tertentu atau menawarkan peluang-peluang.

Dengan demikian, keseluruhan dinamika yang terjadi pada ruang berita dapat dilihat sebagai serangkaian kecil interaksi antara sruktur dan agensi pada beberapa konteks historis spesifik, secara khusus sebagai kontestasi antara pemilik dan jurnalis dikaitkan dengan peluang dan kemampuan mereka menguasai elemenelemen pada struktur, dimana kontestasi ini dilatarbelangi oleh ideologi masingmasing (sejalan dengan perkembangan kapitalisme tertentu).

\section{Bahasa dalam Wacana Media}

$$
\text { Susanne K. Langer (dalam }
$$
Mulyana, 2000: 46) mengatakan bahwa salah satu kebutuhan pokok manusia adalah kebutuhan akan simbolisasi atau penggunaan lambang-lambang. Sobur, mengutif pendapat Wieman dan Walter (dalam Johannesen, 1996: 46), mengatakan bahwa salah satu sifat dasar manusia, adalah kemampuan menggunakan simbol. Tanda-tanda (signs) adalah basis dari seluruh komunikasi (Littlejohn, 1996: 64).

Menarik apa yang dikatakan para pakar di atas. Littlejohn misalnya, mengatakan bahwa tanda adalah basis 
dari seluruh komunikasi. Apa yang akan terjadi, jika kita tidak mengenal tanda, atau seandainya tanda-tanda itu tidak ada dibenak kita. Kita mungkin tidak akan pernah bisa berkomunikasi satu sama lainnya. Manusia dengan perantaraan tanda-tanda, dapat melakukan komunikasi dengan sesamanya. Tanda-tanda (signs) menunjuk bentuk pesan secara keseluruhan yaitu pesan verbal dan non verbal, dan bahasa yang kita gunakan sehari-hari merupakan wujud dari pesan itu.

Bahasa merupakan salah satu sistem tanda (signs) itu. Dengan bahasa manusia yang satu atau satu entitas dapat berkomunikasi dengan manusia atau entitas lainnya. Dengan bahasa kita dapat mengungkapkan apa yang ada dipikiran kita kepada lawan bicara, demikian juga sebaliknya. Dengan bahasa, kita mengetahui sejarah masa lalu. Dengan bahasa, kita dapat membaca lingkungan sosial di sekitar kita. Dengan bahasa, kita dapat memahami orang atau kelompok lain, demikian juga sebaliknya. Dalam konteks penelitian ini, komunikasi yang dimaksud adalah komunikasi antara media massa sebagai komunikator dan khalayak sebagai komunikan.

Realitas media (teks berita) adalah hasil konstruksi media. Dengan demikian, realitas media bukanlah produk yang orisinil, tapi produk second hand dengan media sebagai agen konstruksinya. Ini adalah sinyalemen bahwa, realitas media tidak merefleksikan realitas sosial yang sesungguhnya, melainkan realitas second hand. Dengan bahasa lain, fakta yang sesungguhnya adalah bahwa, realitas media (teks berita) merefleksikan subjektivitas media dan wartawan, karena memang, realitas media diproduksi oleh media yang secara notabene tidak lepas dari subjektivitas individual wartawan, organisasi, kepemilikan dan kepentingan lain diluar media itu sendiri.

Bahasa merupakan perangkat utama media dalam rangka merekonstruksi fakta-fakta sosial itu. Hal ini menunjuk adanya manipulasi terhadap realitas, dengan bahasa sebagai alat manipulasinya. Pemilihan kosakata, dan kalimat tertentu untuk menggambarkan sebuah peristiwa yang terjadi, dengan harapan mengarahkan persepsi khalayak untuk berpikir sesuai dengan yang diinginkan media atau dalam rangka membentuk opini publik, merupakan rantai kemenangan yang harus dilakukan oleh media.

Bahasa dalam konteks ini (Sobur, 2001: 88) bukan saja sebagai alat merepresentasikan realitas, namun juga menentukan relief seperti apa yang akan diciptakan oleh bahasa tentang realitas tersebut. Akibatnya, media massa mempunyai peluang yang besar untuk mempengaruhi makna dan gambaran yang dihasilkan dari realitas yang 
dikonstruksikannya. Dijelaskan Sobur, bahwa kegiatan jurnalistik memang menggunakan bahasa sebagai bahan baku guna memproduksi berita. Akan tetapi, bagi media, bahasa bukan sekedar alat komunikasi untuk menyampaikan fakta, informasi, atau opini. Bahasa juga bukan sekedar alat komunikasi untuk menggambarkan realitas, namun juga menentukan gambaran atau citra tertentu yang hendak ditanamkan kepada publik. Terkait hal ini, Becker (Littlejohn 1996: 236) mengatakan bahwa setiap bahasa setiap simbol hadir bersamaan dengan ideologi, maka pilihan atas seperangkat simbol, disadari atau tidak, merupakan pilihan atas ideologi.

Ideologi dalam kajian kritis, dipandang sebagai faktor eksternal media massa, yang ikut mempengaruhi konstruksi realitas (teks media). Dengan nilai-nilai yang dipercaya dan diyakininya, media massa, dengan bahasa sebagai perangkatnya, memberikan cara pandang tertentu kepada khalayak atau pembaca dalam memandang fenomena sosial. Media massa mencoba mengarahkan khalayak atau pembaca dalam mendefinisikan sesuatu, sesuai dengan yang diinginkan media massa itu sendiri sebagai pihak yang memproduksi makna. Terkait dengan hal ini, Fowler dkk (Eriyanto, 2001: 137) mengatakan bahwa bahasa pada dasarnya bersifat membatasi kita - kita diajak berfikir untuk memahami seperti itu, bukan yang lain. Singkatnya, Piliang (2004: 134) mengatakan bahwa membincang media tidak lepas dari ideologi yang membentuknya, yang pada akhirnya mempengaruhi bahasa (gaya, ungkapan, kosakata, tanda) yang digunakan dan pengetahuan (keadilan, kebenaran, realitas) yang dihasilkannya.

Media massa adalah sarana yang strategis, dalam rangka menanamkan ideologi dan nilai-nilai tertentu. Hal ini karena media menurut Althusser (1984), memiliki kesanggupan sebagai sarana legitimasi. Media massa sebagaimana lembaga-lembaga pendidikan, agama, seni, dan kebudayaan merupakan alat dari yang bekerja secara ideologis untuk membangun kepatuhan khalayak "ideologi aparatus".

Berbeda dengan apa yang disampaikan Althusser di atas, Gramsci (1991), menilai media sebagai ruang dimana berbagai ideologi dipresentasikan. Hal ini mengindikasikan bahwa media bisa menjadi sarana diseminasi dan alat legitimasi ideologi kelas dominan atas wacana publik. Akan tetapi, disisi yang lain media juga menjadi alat resistensi terhadap kelas dominan itu.

Menurut Gramsci (ibid, hlm: 57-58), dominasi kekuasaan dipejuangkan, disamping lewat kekuatan senjata, juga melalui persetujuan/penerimaan publik, yaitu diterimanya ide dan gagasan tertentu 
oleh masyarakat luas, yang diekspresikan melalui mekanisme opini publik.

Terkait dengan hal ini, pembentukan opini publik merupakan isu sentral dalam prinsip hegemoni, yang mengisyaratkan adanya ruang publik sebagai mediasi. Dalam konteks inilah, Gramsci menilai penting adanya institusiinstitusi yang berperan menyebarluaskan hegemoni ideologi. Gramsci, kemudian menjelaskan institusi dan strukturnya sebagai alat hegemoni seperti sekolah, rumah ibadah, nama jalan dan media massa.

Media massa sebagai simbol ruang publik, yang di dalamnya bahasa dan simbol-simbol diproduksi dan disebarkan, tidak dilihat Gramsci sebagai sebuah alat hegemoni yang pasif semata. Sebagaimana yang dikatakan sebelumnya, media massa membentuk sebuah ruang tempat berlangsungnya perang bahasa atau perang simbol untuk memperebutkan ruang penerimaan publik atas gagasangagasan ideologi yang diperjuangkan.

Dalam rangka memperebutkan penerimaan publik ini, maka kekuatan bahasa dan kekuatan simbol menjadi sangat penting. Gramsci melihat makna (meaning) dan nilai-nilai (value) dominan yang dihasilkannya (lewat berbagai media) sangat menentukan proses dominasi sosial itu sendiri. Meskipun demikian, dalam prinsip hegemoni, makna, bahasa dan nilai-nilai dominan tersebut tidak pernah berada dalam kondisi stabil. Keberadaannya selalu dipertanyakan, digugat, ditantang dan dilawan lewat berbagai bentuk perjuangan politik pertandaan (politic of signification).

\section{Daftar Pustaka}

Arthur Asa Berger, 1991. Media Analysis Techniques, resived edition, Beverly Hills : Sage Publication;

Bachtiar Effendy, 2000. "Media Massa dan Politik" dalam Sudrajat A.S (ed), Repolitisasi Islam: Pernahkah Islam Berhenti Berpolitik?, Bandung: Mizan;

Burhan Bungin, 2008. Konstruksi Sosial Media Massa, Jakarta: Kencana;

Chris Barker, 2000. Cultural Studies: Theory dan Praktik, Nurhadi (penerjemah), Yogyakarta: Kreasi Wacana;

Dedy N. Hidayat, 2000. Revolusi Mei: Runtuhnya Sebuah Hegemoni, Jakarta: Gramedia;

Em Griffin, 2003. Communication Theory, A First Look At (Fifth Edition), New York: The McGRAW - HILL COMPANIES, INC;

Eriyanto, 2005. Analisis Framing, Jogjakarta: PT. LkiS Pelangi Aksara; Idi Subandy Ibrahim \& Dedy Djamaludin Malik, 1997. Hegemoni Budaya, Yogyakarta: Bentang; 
John Fiske, 1990. Introduction to

Communication Studies, second edition, London and New York: Routledge;

James Curran \& M. Guravitch, 1996. Media and Society, London: Edward Arnold;

Louis Althusser, 1984. Essay on Ideology, London: Verso;

Listiyono Santoso, Sunarto \& Dkk, 2003. Epistemologi Kiri, Jogjakara: Ar-Russ Media;

Norman K. Denzin \& Yvonna S. Lincoln, 2009. Handbook of Qualitative

Research, Edisi Bahasa Indonesia, Yogyakarta: Pustaka Pelajar;

Nezar Patria \& Andi Arief, 2003. Antonio Gramsi; Negara \& Hegemoni, Jakarta: Pustaka Pelajar;

Roger Simon, 1999. Gagasan-Gagasan Politik Gramsci, Yogyakarta: Pustaka Pelajar \& Insist;

Syaiful Arif, 2001. Pemikiran-Pemikiran Revolusioner, Malang: Averroes Press \& Pustaka Pelajar;

Yasraf Amir Piliang, 2004. Posrealitas: Realitas Kebudayaan Dalam Era Posmetafisika, Yogyakarta: Jalasutra; 